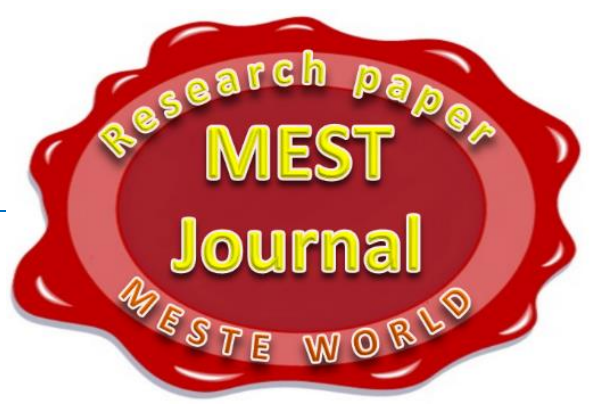

\title{
METR MODEL FOR MEASURING TAX BURDEN ON INVESTMENT IN UKRAINE
}

\author{
Nataliia Nazukova \\ Institute for Economics and Forecasting, Ukrainian National Academy of Sciences, Public \\ Finance Department, Kyiv, Ukraine
}

\section{() MESTE NGO}

\section{JEL Classification: E62, H2, 016}

\begin{abstract}
Taxation is one of the most important determinants of investment. It has a major impact on the cost of capital and the expected net revenue from a given investment. Moreover, different tax burdens distort investment allocation. Recognizing the importance of these effects, this study tries to identify the tax induced distortions associated with the current system of taxation, and to find out which tax incentives are the most important for inducing investments in Ukraine. The study attempts to measure the real tax burden on capital investment by using the marginal effective tax rate (METR) as a quantitative indicator. The research includes both general and selective tax incentives, drawing high attention to the incentives acting through the system of corporate income taxation. The calculations are divided into two main parts: the first part - with due regard to general tax provisions (CIT - corporate income tax rate, treatment of dividends, capital recovery incentives, and import duty); the second one - with widening METR calculation by taking into account selective investment tax incentives (tax holidays, investment tax credits, preferential CIT rates). The paper also examines whether general or selective tax incentives' implication changes the results of calculations.
\end{abstract}

Keywords: corporate income tax rate, CIT, investment incentives, marginal effective tax rate, METR, tax burden on capital investments, real rates of return before and after tax, general and selective investment tax incentives

\section{INTRODUCTION}

The most important changes in tax system, fixed in the Tax Code of Ukraine, which came into force on 01.01.2011, concern the mechanisms for

Address of the author:

Nazukova Nataliia

䒠trotsn@ukr.net encouraging investment and innovation activities of enterprises. The mechanisms should motivate taxpayers to modernize their industrial and technological base by increasing their own investment resources and by attracting foreign direct investments.

Most tax incentives with the longest period of validity were established within corporate tax 
system. Lowering statutory corporate income tax (CIT) rate is one of the least distorting forms of investment incentives. It is largely due to the fact that the statutory rate applies uniformly to all profitable business activities (so, without biasing the allocation of capital, the form of financing, etc.). This type of tax measure is administrative simple, since no complexity is added to the system of tax monitoring and tax administration. Lowering standard tax rate is a transparent measure that reduces the incentives for abusive tax planning.

Nevertheless, the measure has an important drawback - its effect relative to the revenue loss. This is because the tax relief falls on all businesses, regardless of their willing to undertake new investments.

In Ukraine, the nominal CIT rate was reduced in 2004 (from 30 to 25\%), in 2011 (from 25 to $23 \%$ ), in 2012 (from 23 to $21 \%$ ), in 2013 (from 21 to $19 \%$ ), and in 2014 (from 19 to $18 \%$ ), and a further decline is planned for $2015-2016$ (17 to $16 \%$ ). Due to the decline, in 2012 Ukraine was positioned as one of the countries with the lowest marginal effective tax rate (METR) for capital investment. For instance, according to the calculations of D. Chen and J. Mintz (2012), decline of CIT rate during 2011-2012, by two points per year, from $25 \%$ to $21 \%$, combined with generous depreciation allowance, yielded a very low METR on investment in fixed assets of $6 \%$.

Table 1. Marginal effective tax rate on capital investment in some countries, 2012 vs. 2005

\begin{tabular}{|c|c|c|c|c|c|c|c|}
\hline & \multicolumn{3}{|c|}{ Marginal Effective Tax Rate } & \multicolumn{3}{|c|}{$\begin{array}{c}\text { METR ranking in } \\
\text { descending order }\end{array}$} & \multicolumn{3}{|c|}{$\begin{array}{c}\text { Statutory Company } \\
\text { Income Tax Rate }\end{array}$} \\
\cline { 2 - 8 } & 2012 & 2005 & 2012 & 2005 & 2012 & 2005 & + +-\% point \\
\hline Argentina & 43.2 & 43.2 & 1 & 3 & 35.0 & 35.0 & 0.0 \\
\hline India & 33.5 & 37.8 & 6 & 6 & 32.45 & 36.6 & -4.1 \\
\hline Colombia & 33.4 & 26.3 & 7 & 23 & 33.0 & 35.0 & -2.0 \\
\hline Brazil & 31.6 & 35.1 & 8 & 11 & 34.0 & 34.0 & 0.0 \\
\hline Japan & 30.4 & 31.9 & 9 & 16 & 36.8 & 39.5 & -2.7 \\
\hline UK & 26.7 & 29.7 & 14 & 19 & 24.0 & 30.0 & -6.0 \\
\hline Germany & 24.6 & 34.2 & 21 & 13 & 30.2 & 38.9 & -8.7 \\
\hline Poland & 14.5 & 14.5 & 55 & 72 & 19.0 & 19.0 & 0.0 \\
\hline Ukraine & 5.6 & 7.5 & 87 & 86 & 21.0 & 25.0 & -4.0 \\
\hline
\end{tabular}

Source: Duanjie Chen and Jack Mintz (2012, p. 9)

Though, results of the study by D. Chen and J. Mintz do not correspond to the statistics of inflow of foreign direct investments in Ukraine. E.g., among the countries that, according to the calculation of marginal tax rates, were specified in the top ten with the highest burden on investments, had much higher absolute figures of foreign direct investments. As shown in the schedule, Argentina, India, Colombia, Brazil (which have a high estimated tax burden on investment and occupy respectively the 1st, 6th, 7th and 8th places in the top ten) run ahead of Ukraine by the level of investment, despite the fact that Ukraine occupies 87th place by severity of burden among the 90 countries surveyed by $D$. Chen and J. Mintz.

Furthermore, other studies of the tax burden on capital investment indicate, that Ukraine has one of the highest effective tax rates in Europe. For example, according to the study of changes in corporate taxation in developing countries, conducted by S. M. Ali Abbas and Alexander Klemm, with Sukhmani Bedi and Junhyung Park (2012), due to the reduction of CIT in 2004, corporate effective tax rates in Ukraine has decreased. But both the initial effective tax rate and the reduced one, were high: $41.9 \%$ and $32.7 \%$ for METR before and after the reduction. 


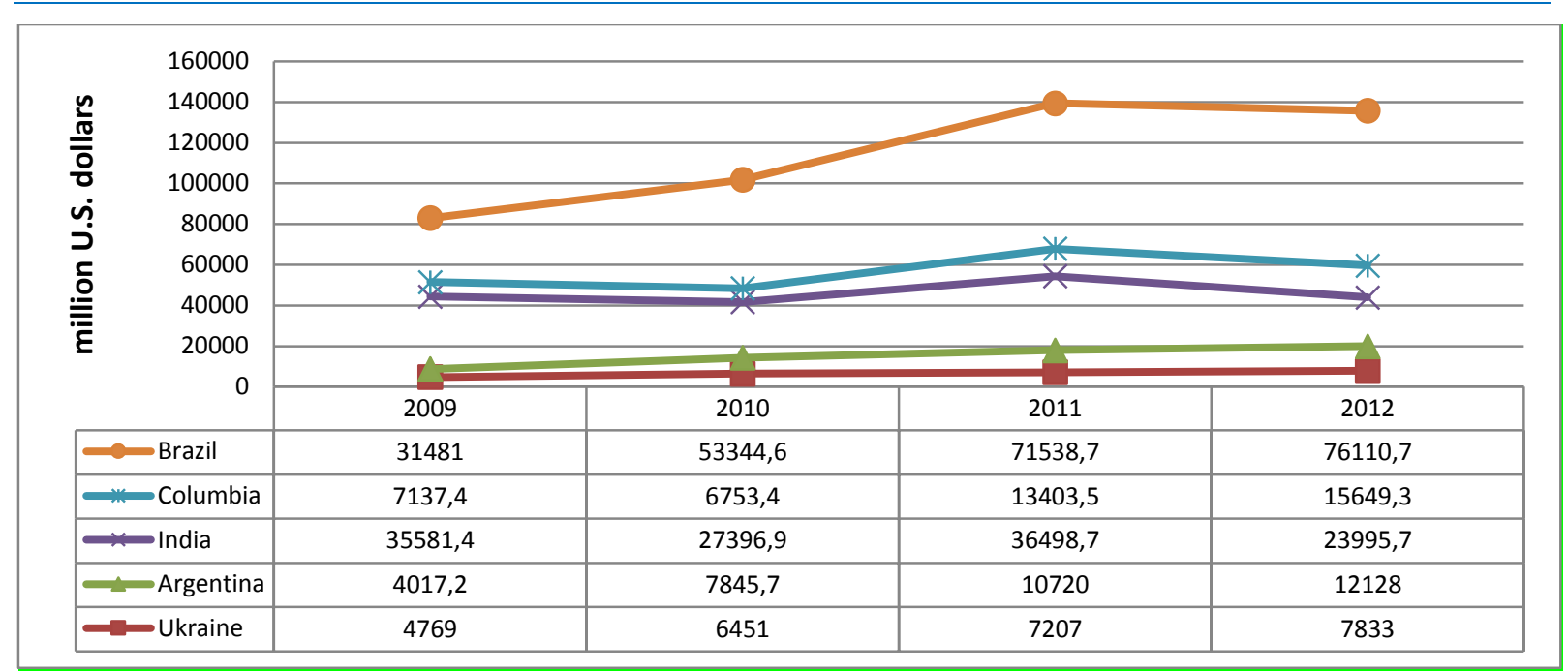

Figure 1. The amount of foreign direct investments in some countries during 2009-2012

Source: The World Bank

Table 2. Episodes of large effective tax rate changes in Ukraine (In\%age points)

\begin{tabular}{|l|c|c|c|c|c|}
\hline & Start year & Duration & $+/-$ & Start level & End level \\
\hline EATR & 2004 & 1 & -9.5 & 40.3 & 30.7 \\
\hline METR & 2004 & 1 & -9.2 & 41.9 & 32.7 \\
\hline
\end{tabular}

Source: S. M. Ali Abbas et al. (2012).

After a decline of the nominal rate and corresponding reduction of effective rates in 2004, the level of corporate taxation in Ukraine continued its growth. According to estimates of the Association of Separate and Independent Accounting and Consulting Firms (AGN International, 2008) in 2008 the effective corporate tax rate increased significantly - to $42 \%$.

Considering that the results of studies on tax impact on capital investments in Ukraine differ significantly, we have conducted our own calculations in order to highlight the main issues for investment tax burden analysis in Ukraine.

\section{METR AS A TOOL FOR ANALYZING TAX BURDEN ON INVESTMENTS IN UKRAINE}

Changes in the statutory tax rate only partially shows the extent to which the tax system influences the rate of return and affects the allocation of capital. This is because tax burden on any type of business activity is influenced by many other factors: exemptions, deductions, exclusions, allowances, and credits, and also the nature of the investment itself (internal or external type of financing).

Measuring the tax burden on investment is a difficult task. In the literature, the dominating concept is the effective marginal tax rate measure introduced by King and Fullerton (1984). On the basis of statutory tax rates and tax bases, King and Fullerton consider a permanent increase in the capital stock of a representative firm and calculate the tax burden on the basis of the difference between the rate of return of the marginal investment and the return required by the investor. Therefore, METRs measure the extent to which the tax system reduces the real rate of return on investment, at the margin.

Their methodology has further been applied by Dunn and Pellechio (1990) who developed the Marginal Effective Tax Rate model for their survey work on the taxation of business income in developing countries. They have represented a very useful and valuable tool to calculate effective tax rates for a variety of tax policies, types of investments and tax incentives. 
Useful discussions of the METR can be found in Chua (1995); Shah (1995); OECD (2000); Zee, Stotsky and Ley (2002). Gordon, Kalambokidis and Slemrod (2003) have suggested another measure of the marginal tax burden on investment. The difference to King and Fullerton (1984) is that this new measure is a backward looking concept. Under certain assumptions it can be shown that the depreciation deductions in one period can be used to approximate the future deductions of the investment project under consideration. However, due to its strict assumptions this new measure has several shortcomings when applied to real world data.

The analysis in this paper includes the exploration of the main idea of the Dunn and Pellechio Marginal Effective Tax Rate model. The model is based on assuming a hypothetical project with a particular internal, before-taxes, rate of return. METR generates a cash flow for the project. Given the appropriate information on tax policy, the model applies this information to the cash flow and derives the internal rate of return for the aftertax cash flow. The effective tax rate (ETR) is the difference between the before and after-tax rates of return expressed as a\%age of the before-tax rate of return. On the basis of this idea, we develop a method of evaluating the tax burden on investments and correcting them for errors due to tax law complexities. The most important purpose of this paper is to apply our method to Ukrainian balance sheet data.

METR is a measure that shows the extent to which the tax system reduces the rate of return on investment, taking into account not only statutory tax rate, but other technical parameters of the tax system: investment incentives, loss carry forward and carry back for income tax purpose, capital gains taxation etc.

The definition of "tax incentives" encompass both general and selective incentives, it should cover both direct and indirect tax measures. Tax incentives should be included in the METR model as a set of tools: low statutory tax rates, preferential tax rates, tax holidays, capital recovery incentives - accelerated depreciation and initial capital allowances, investment tax credits, treatment of dividends, extra deductions, and also indirect tax incentives (export incentives, reduced import duty on capital goods and raw materials, etc.).

The research includes both general and selective tax incentives, drawing high attention to the incentives acting through the system of corporate income taxation. The calculations are divided into two main parts: 1) METR calculation with due regard to general tax provisions (CIT rate, treatment of dividends, capital recovery incentives, and import duty); 2) widening the METR calculation by taking into account selective investment tax incentives (tax holidays, investment tax credits, preferential CIT rates).

\subsection{METR calculation for general investment tax incentives in Ukraine}

The model of tax burden on investment in Ukraine should include tax parameters that are the core factors affecting investment decisions. We propose that the general calculations include such tax factors: statutory CIT rate, withholding tax, import duty on capital goods, and annual capital allowance.

Though the METR measures the extent to which the tax system reduces the real rate of return on investment, at the margin, it can be expressed as follows:

$$
\text { METR }=\frac{(\text { RORbT }- \text { RORaT })}{R O R b T} * 100 \%
$$

where:

$\mathrm{RORbT}$ and RORaT are the real rates of return before and after tax.

To simplify the data problems, we have constructed representative examples of investment projects that conclude basic data (general tax parameters).

For Ukraine, the CIT rate is $18 \%$, withholding tax is $15 \%$; average dividend payout ratio is $30 \%$. We have calculated three scenarios for different import duties: $0 \%, 5 \%$, and $10 \%$. It is important to note, that the calculation is made only for internal sources of financing. 
Table 3. Marginal effective tax rates for general tax parameters

\begin{tabular}{|l|c|c|c|c|c|c|}
\hline & \multicolumn{3}{|l|}{$25 \%$ capital allowances } & \multicolumn{3}{l|}{$50 \%$ capital allowances } \\
\cline { 2 - 7 } & $\begin{array}{l}10 \% \text { import } \\
\text { duty }\end{array}$ & $\begin{array}{l}5 \% \text { import } \\
\text { duty }\end{array}$ & $\begin{array}{l}0 \% \text { import } \\
\text { duty }\end{array}$ & $\begin{array}{l}10 \% \text { import } \\
\text { duty }\end{array}$ & $\begin{array}{l}5 \% \text { import } \\
\text { duty }\end{array}$ & $\begin{array}{l}0 \% \text { import } \\
\text { duty }\end{array}$ \\
\hline $\begin{array}{l}100 \% \text { dividend } \\
\text { reinvestment }\end{array}$ & 96.6 & 83.5 & 73.5 & 39.5 & 38.1 & 36.8 \\
\hline $\begin{array}{l}50 \% \text { dividend } \\
\text { reinvestment }\end{array}$ & 151.4 & 130.9 & 115.2 & 61.9 & 59.7 & 57.6 \\
\hline $\begin{array}{l}0 \% \text { dividend } \\
\text { reinvestment }\end{array}$ & 206.2 & 178.2 & 156.9 & 84.3 & 81.3 & 78.5 \\
\hline
\end{tabular}

As tax burden on investment is influenced not only by tax conditions, but also by the structure of financial sources and types of assets (rates of depreciation/amortization), the calculation divides onto three options of dividend reinvestment (full capitalization, 50/50, and none), and the number of possible scenarios increase due to the inclusion of different capital allowance rates in the analysis. Though capital allowances reduce the user cost of capital, we considered two arbitrary options for capital depreciation: the first year deduction of costs is $25 \%$ and the first year deduction of costs is $50 \%$. We also considered the effect of the "capital allowance tax shield".

The significance of the results is in evaluation of relative efficiency of fiscal policy measures, in particular investment tax incentives. The lowest marginal effective tax rate of new investment accounts for a scenario with zero import duty, full dividend reinvestment and, what's most importantly, - high capital allowance rate - 50\%.

Table 4. Marginal effective tax rates for general tax parameters, course of calculation

\begin{tabular}{|l|l|l|l|l|l|l|l|l|l|l|l|}
\hline $\begin{array}{l}\text { Import } \\
\text { duty }\end{array}$ & $\begin{array}{l}\text { Distributed } \\
\text { profit (in the } \\
\text { form income } \\
\text { dividends) }\end{array}$ & $\begin{array}{l}\text { Net } \\
\text { inco }\end{array}$ & $\begin{array}{l}\text { UCC } \\
25 \% \\
\text { depreci } \\
\text { ation }\end{array}$ & $\begin{array}{l}\text { UCC } \\
50 \% \\
\text { deprecia } \\
\text { tion }\end{array}$ & $\begin{array}{l}25 \% \\
\text { deprecia } \\
\text { tion tax } \\
\text { shield }\end{array}$ & $\begin{array}{l}50 \% \\
\text { deprecia } \\
\text { tion tax } \\
\text { shield }\end{array}$ & $\begin{array}{l}\text { UCC } \\
\text { after tax, } \\
25 \% \\
\text { deprecia } \\
\text { tion }\end{array}$ & $\begin{array}{l}\text { UCC } \\
\text { after tax, } \\
50 \% \\
\text { deprecia } \\
\text { tion }\end{array}$ & $\begin{array}{l}\text { METR, } \\
25 \% \\
\text { depreci } \\
\text { ation }\end{array}$ & $\begin{array}{l}\text { METR, } \\
50 \% \\
\text { depreci } \\
\text { ation }\end{array}$ \\
\hline $\mathbf{0 . 1}$ & 0.0 & 0.7831 & 1.1 & 0.275 & 0.55 & 0.04950 & 0.099 & 0.7755 & 0.451 & 96.61 & 39.51 \\
\hline $\mathbf{0 . 1}$ & 0.123 & 0.6601 & 1.1 & 0.275 & 0.55 & 0.04950 & 0.099 & 0.7755 & 0.451 & 151.40 & 61.91 \\
\hline $\mathbf{0 . 1}$ & 0.246 & 0.5371 & 1.1 & 0.275 & 0.55 & 0.04950 & 0.099 & 0.7755 & 0.451 & 206.19 & 84.32 \\
\hline $\mathbf{0 . 0 5}$ & 0.0 & 0.7831 & 1.05 & 0.2625 & 0.525 & 0.04725 & 0.0945 & 0.74025 & 0.4305 & 83.50 & 38.09 \\
\hline $\mathbf{0 . 0 5}$ & 0.123 & 0.6601 & 1.05 & 0.2625 & 0.525 & 0.04725 & 0.0945 & 0.74025 & 0.4305 & 130.86 & 59.68 \\
\hline $\mathbf{0 . 0 5}$ & 0.246 & 0.5371 & 1.05 & 0.2625 & 0.525 & 0.04725 & 0.0945 & 0.74025 & 0.4305 & 178.21 & 81.28 \\
\hline $\mathbf{0 . 0}$ & 0.0 & 0.7831 & 1.0 & 0.25 & 0.5 & 0.04500 & 0.09 & 0.705 & 0.41 & 73.53 & 36.76 \\
\hline $\mathbf{0 . 0}$ & 0.123 & 0.6601 & 1.0 & 0.25 & 0.5 & 0.04500 & 0.09 & 0.705 & 0.41 & 115.22 & 57.61 \\
\hline $\mathbf{0 . 0}$ & 0.246 & 0.5371 & 1.0 & 0.25 & 0.5 & 0.04500 & 0.09 & 0.705 & 0.41 & 156.92 & 78.46 \\
\hline
\end{tabular}

As one can see, a scenario with zero import duty, full dividend reinvestment and $50 \%$ capital allowance rate has the lowest METR $-36.76 \%$. The return on investment ratio in this scenario is
0.5371 , and user cost of capital (UCC) after tax is 0.41 . In this case, the tax rules are investment inductive. 
In contrast to the mentioned scenario, the scenario which takes into account $25 \%$ capital allowance is inefficient from investors' perspectives, as METR is the highest. Thus, when capital allowance rate is $25 \%$, and import duty is $10 \%$, the return on investment ratio varies within $0.54-0.78$ (depending on the dividend reinvestment ratio), and the cost of capital is 0.78 . Thus, the ratio "return on investment-to-the cost of capital" varies from 0.69 to 1.0 , i.e. the effect of the tax system leads to the reduction of income by 31 to $100 \%$, and capital allowances allow to write off only $22 \%$ of user cost of capital during the first year of investment (UCC after tax is 0.78 ).

Therefore, the METR model used for the assessment of relative effect of taxes and depreciation on corporate investments allows us to draw conclusions about the close dependence of the rate of return on investment and: 1) tax rules; 2) depreciation of capital; 3) the distribution of income. The calculations show that tax policy imposes a strong bias on investment patterns even in the absence of selective tax incentives.

It is obvious, that the greatest impact on METR has depreciation (capital allowance). It opens a question of effectiveness of CIT lowering, introduced by the Tax Code. Would it be more effective to leave the old tax rate 25 per cent, and, in same time, introduce the reduced rate, say 10 per cent, for companies-investors? Especially taking into account, that flat reduction of the standard CIT (from 25 to 18 per cent in 2014) leads to revenue loss. In my opinion, based particularly on the METR calculations, it would be more efficient (from the point of investment activity) to leave 25 per cent standard CIT, and to introduce the reduced one, that would be applied to companies, undertaking investments. That means that introduction of differentiated tax rates would have greater effect on investment activities.

\subsection{METR calculation for selective investment tax incentives in Ukraine}

The tax burden can be reduced in two ways: by making the general tax system more attractive, or by offering selective incentives. There are some important notes on selective tax incentives: selective incentives require screening procedures, which can create significant administrative costs and delays; to ensure accountability, full and prompt public disclosure should be a firm requirement for any system of selective tax incentives; selective tax breaks (if used) should narrowly focus on activities that are likely to deliver high payoff in terms of policy goals, and which would not be undertaken without special incentives. Furthermore, any selective screening process can be subverted by political maneuvering.

Among the most common selective tax incentives (in terms of type of industry or business), undertaken in Ukraine are: tax holidays, investment tax credits and preferential tax rates.

Due to the provision of corporate tax incentives, the revenue loss in 2011 increased more than 7 times: from 2 billion UAH in 2010 to 15.4 billion UAH in 2011, and remained significant in 2012, 5.1 billion UAH. Accordingly, the size of income tax incentives as a share of budget expenditures has increased from 5.7\% in 2010 to $26 \%$ and $31 \%$ in 2011-2012, respectively.

An observation of the tax incentives in Ukraine allows us to draw conclusions on the lack of investment and innovation targeting. In this regard, A. Sokolovska, T. Efimenko, I. Lunina, R. Balakin, V. Ziatkovskiy (2006) suggest ways to improve existing mechanisms for providing tax incentives, and also to enact a system of tax efficiency monitoring (by analyzing budget losses) (Sokolovska, 2011). However, the problem of assessment of investment tax incentives' efficiency remains unsolved, particularly taking into account the fact that the wearout level of capital equipment in Ukrainian industry is about $75 \%$.

The METR model provides a measure for evaluating the extent to which various tax incentive packages improve the rate of return for representative investment projects, at the margin.

So, next off, we have extended the representative examples of investment projects by inclusion of tax incentives provided by the acting corporate income taxation system of Ukraine. 
Table 5. Type and industry distribution of income tax incentives, operating during 2011-2012

\begin{tabular}{|c|c|c|}
\hline $\begin{array}{l}\text { Type of } \\
\text { investment } \\
\text { tax incentive }\end{array}$ & What does the incentive provide? & Industry/services \\
\hline Tax Holidays & Income from operations is exempt from corporate income taxation & Energy production \\
\hline$-x$ Holidays & $\begin{array}{l}\text { Income from domestic production of book products, except erotic } \\
\text { production, is exempt from corporate income taxation. }\end{array}$ & Publishing activities \\
\hline Tax Holidays & $\begin{array}{l}\text { Income from operations is exempt from corporate income taxation } \\
\text { (except businesses working with customer-supplied raw materials). }\end{array}$ & $\begin{array}{l}\text { Consumer goods } \\
\text { industry }\end{array}$ \\
\hline Tax Holidays & $\begin{array}{l}\text { Income from core industry operations, and R\&D operations are exempt } \\
\text { from corporate income taxation. }\end{array}$ & Aircraft industry \\
\hline Tax Holidays & $\begin{array}{l}\text { Corporate income tax relief falls on: income earned by domestic } \\
\text { manufacturers of device, machinery, and equipment, if the device, } \\
\text { machinery, and equipment are designed to produce and reconstruct } \\
\text { technical and conveying equipment (including self-powered } \\
\text { agricultural machinery and powerplants) that expend biofuel. }\end{array}$ & $\begin{array}{l}\text { Machinery } \\
\text { manufacturing }\end{array}$ \\
\hline $\begin{array}{r}\text { Investment } \\
\text { tax credit }\end{array}$ & $\begin{array}{l}80 \% \text { of income earned from sales of own-produced goods on Ukrainian } \\
\text { customs territory is exempt from corporate income taxation: renewable } \\
\text { energy-fired equipment; materials, raw materials, equipment and } \\
\text { complete units, used for energy production from renewable sources; } \\
\text { energy efficient equipment, materials, products, operation of which } \\
\text { provides economizing and rational use of energy resources; means for } \\
\text { measurement, control and management of fuels and energy resources } \\
\text { costs; equipment for alternative fuels production. }\end{array}$ & $\begin{array}{l}\text { Food and } \\
\text { pharmaceutical, } \\
\text { machinery } \\
\text { processing industries }\end{array}$ \\
\hline Tax Holidays & Income from operations is exempt from corporate income taxation. & Shipbuilding industry \\
\hline Tax Holidays & Income from operations is exempt from corporate income taxation. & $\begin{array}{l}\text { Machine } \\
\text { manufacturing for } \\
\text { agricultural sector }\end{array}$ \\
\hline $\begin{array}{r}\text { Investment } \\
\text { tax credit }\end{array}$ & $\begin{array}{l}\text { Funds or cost of property, possessed by film producers and/or } \\
\text { animation producers, that are used for production of national films, are } \\
\text { excluded from taxable income. }\end{array}$ & Film production \\
\hline Tax Holidays & Income from sales of biofuel is exempt from corporate income taxation. & Biofuel production \\
\hline Tax Holidays & $\begin{array}{l}\text { Income from hotel services provision is exempt from corporate income } \\
\text { taxation (five star, four star and three star hotels, new and rebuild or } \\
\text { reconstructed) if income earned by the entrepreneur from } \\
\text { accommodation services comes up to at least } 75 \% \text { of total income } \\
\text { earned during taxable period in which tax relief is in force. }\end{array}$ & Hotel business \\
\hline $\begin{array}{r}\text { Preferential } \\
\text { tax rate }\end{array}$ & $\begin{array}{l}\text { From } 01.01 .2013 \text { until } 01.01 .2023 \text { for IT-industry entrepreneurs } 5 \% \\
\text { CIT rate is set. }\end{array}$ & IT industry \\
\hline
\end{tabular}

Source: Ministry of Revenue and Duties of Ukraine

Table 6. Marginal effective tax rates for investment tax incentives

\begin{tabular}{|c|c|c|c|c|c|c|c|}
\hline & \multirow{2}{*}{$\begin{array}{l}\text { Dividend } \\
\text { reinvestment } \\
\text { rate }\end{array}$} & \multicolumn{3}{|c|}{$25 \%$ capital allowances } & \multicolumn{3}{|c|}{$50 \%$ capital allowances } \\
\hline & & $\begin{array}{l}10 \% \text { import } \\
\text { duty }\end{array}$ & $\begin{array}{l}5 \% \text { import } \\
\text { duty }\end{array}$ & $\begin{array}{l}0 \% \text { import } \\
\text { duty }\end{array}$ & $\begin{array}{l}10 \% \text { import } \\
\text { duty }\end{array}$ & $\begin{array}{l}5 \% \text { import } \\
\text { duty }\end{array}$ & $\begin{array}{l}0 \% \text { import } \\
\text { duty }\end{array}$ \\
\hline \multirow{3}{*}{$\begin{array}{l}\text { Tax holidays, } 0 \% \mathrm{CIT} \\
\text { rate }\end{array}$} & $100 \%$ & 25.7 & 21.2 & 18.0 & 10.0 & 9.5 & 9.0 \\
\hline & $50 \%$ & 111.4 & 91.7 & 78.0 & 43.3 & 41.0 & 39.0 \\
\hline & $0 \%$ & 197.1 & 162.3 & 138.0 & 76.7 & 72.6 & 69.0 \\
\hline \multirow{3}{*}{$\begin{array}{l}\text { Investment tax credit, } \\
80 \% \text { of income is } \\
\text { excluded from tax } \\
\text { base }\end{array}$} & $100 \%$ & 42.9 & 35.7 & 30.6 & 16.9 & 16.1 & 15.3 \\
\hline & $50 \%$ & 121.1 & 100.9 & 86.5 & 47.7 & 45.3 & 43.2 \\
\hline & $0 \%$ & 199.3 & 166.1 & 142.3 & 78.5 & 74.6 & 71.1 \\
\hline \multirow{3}{*}{$\begin{array}{l}\text { Preferential tax rate, } \\
5 \% \text { CIT rate }\end{array}$} & $100 \%$ & 49.1 & 41.1 & 35.3 & 19.4 & 18.5 & 17.7 \\
\hline & $50 \%$ & 124.6 & 104.3 & 89.6 & 49.2 & 46.9 & 44.8 \\
\hline & $0 \%$ & 200.1 & 167.4 & 143.9 & 79.1 & 75.4 & 72.0 \\
\hline
\end{tabular}


In the extended calculation, the basic data (general tax parameters) are held constant (the CIT rate is $18 \%$, withholding tax is $15 \%$; dividend payout ratio is $30 \%$ ) while other factors that affect the METR (investment tax incentives) are changeable: tax holidays, investment tax credit, and preferential tax rate. Though, the changeable factors that have constructed the calculation, include: $5 \%$ preferential CIT rate, $0 \% \mathrm{CIT}$ rate (tax holidays), and the exclusion of $80 \%$ of corporate income from the tax base. As tax burden on investment is influenced not only by tax conditions, but also by the structure of financial sources and types of assets, the calculation includes three options of dividend reinvestment (full capitalization, 50/50, and none), and two options for capital allowance rates (25 and $50 \%$ ).

Using this approach, one can isolate the impact of various factors by holding constant other factors that affect the METR. The examples are constructed to provide information needed to calculate rates of return before and after taxes. This approach can be used for analyzing tax systems across countries.

The METR calculation for investment tax incentives allows us to draw some conclusions: 1) the most effective tax instrument for lowering METR on new investment in Ukraine is tax holidays (it can provide the lowest METR of $9 \%$ ), but it should be noted that tax holidays are time- limited; 2) the investment tax credit is more effective instrument for lowering tax burden on investments than the preferential tax rate (METR for investment tax credit, under full capitalization, is $15.3-42.9 \%$, and for the preferential tax rate $17.7-49.1 \%)$.

\section{METR FOR NON-PRODUCTIVE ASSETS IN UKRAINE}

The results of our empirical analysis suggest that the accuracy of indicators varies considerably across firms. We investigate the factors explaining the differences across firms and find that tax depreciation is unexpectedly low in firms with a high share of non-productive assets.

That is why it is important to evaluate the impact of capital allowance on marginal tax rates, when it comes to non-productive assets. In terms of investment, non-productive assets are less attractive: tax credit on VAT cannot be charged, what is more - non-productive assets are not charged to tax depreciation which means the tax shield does not work.

The table represents the results of calculations for two types of assets - productive and nonproductive, under different depreciation charging rates: 25 and $50 \%$. Furthermore we have taken $20 \%$ VAT into the account.

\section{Table 7. Marginal effective tax rates for investments in productive and non-productive assets}

\begin{tabular}{|l|l|c|c|}
\hline \multirow{2}{*}{$\begin{array}{l}\text { Investments in non- } \\
\text { productive assets }\end{array}$} & $100 \%$ dividend reinvestment & $\begin{array}{c}25 \% \text { capital } \\
\text { allowances }\end{array}$ & $\begin{array}{c}50 \% \text { capital } \\
\text { allowances }\end{array}$ \\
\cline { 2 - 4 } & $50 \%$ dividend reinvestment & 340.0 & 54.2 \\
\cline { 2 - 4 } & $0 \%$ dividend reinvestment & 463.0 & 85.0 \\
\hline \multirow{2}{*}{$\begin{array}{l}\text { Investments in } \\
\text { productive assets }\end{array}$} & $100 \%$ dividend reinvestment & 73.5 & 315.7 \\
\cline { 2 - 4 } & $50 \%$ dividend reinvestment & 115.2 & 59.0 \\
\cline { 2 - 4 } & $0 \%$ dividend reinvestment & 156.9 & 80.5 \\
\hline
\end{tabular}

It is obvious that there is essential difference in the tax burden on investments, depending on the type of activity. For example, the company, which accounted for the balance of a large mass of nonproductive assets (energy, transport, telecommunications) will experience higher tax burden on investment resources, than those companies that do not hold such assets. Therefore, even if different companies are subjects to the same basic and selective tax incentives, the tax burden on investments undertaken by such companies will vary, depending on the type of assets in which the companies invest. 
For this reason, as a rule, investment in nonproductive assets (acquisition, construction and improvement of such assets), which include roads, utilities and telecommunications, social infrastructure, are often carried out by the state. As shown in I. Lunina (2011), Ukraine, in terms of cost of investments in fixed assets, ranks last among post-socialist countries.

Therefore, in our view, the main task of implementing investment tax incentives in Ukraine concerns the growth of investment in material and social infrastructure: communications and telecommunications, energy and social field.

The main problem, however, is that there is no "good" criteria of stimulating efficient projects that would not be undertaken in the absence of special incentives. As Krugman (1983) concluded from his review of "popular criteria" for targeting industrial promotion policies, it is very difficult for governments to "devise criteria...which will by and large pick the right industries," or establish procedures that will not be driven by political interests rather than genuine economic benefits. So, we still have much to be done.

\section{CONCLUSIONS}

The basic conclusion iis that the analysis based on the METR model is an effective mean of assessing the tax wedge caused by both general and selective tax incentives. However, it should be noted that this estimate as any other, cannot answer the question of how investment flows will change as a result of the use of certain tax incentives. If non-tax elements of the investment climate are in poor shape, there may be few investments forthcoming even if the METR is very low. On the other hand, high METR rates may not have a significant effect on investment in activities with very favorable conditions, such as oil projects. In other circumstances, many investors consider projects where expected returns are close to the hurdle rate; if so, then a high METR will cut them out, and a low METR will bring them in.

Another feature of the analysis based on the METR model is that the model can not incorporate features of tax laws. If the tax administration is arbitrary, ineffective or corrupt, if entities are looking for ways to use investment incentives in order to reduce the tax burden on the operating or financial performance, the official tax instruments included in the analysis, may be uninformative; than the METR analysis does not reveal much about the effect of the tax system on investment incentives.

Tax incentives may be a useful tool for stimulating productive investment, research and development, and training. But they must be carefully designed and well administered so as to avoid side-effects that diminish productivity by distorting resource allocation, sustaining inefficient or unsustainable activities, and losing revenue needed for other components of the productivity package.

For Ukraine, a kit of analytical tools that can be used in analyzing the effectiveness and impact of tax incentive programs, should be developed. The tool kit should include not only a model for evaluating the marginal effective tax rates, but also: information systems for monitoring effective tax rates; guidelines for monitoring tax expenditures; and guidelines for screening applicants for selective discretionary incentives.

\section{WORKS CITED}

AGN International. (2008). THE AGN EUROPEAN REGION - 2008 Corporate Tax Survey. Retrieved from AGN International - Europe: http://www.agneurope.org/tax/2008/Corporate\%20Tax\%20Article\%202008.pdf

Ali Abbas, S. M., Klemm, A., Bedi, S., \& Park, J. $(2012,01)$. A Partial Race to the Bottom: Corporate Tax Developments in Emerging and Developing Economies. Retrieved from IMF Working Paper-WP/12/28: http://www.imf.org/external/pubs/ft/wp/2012/wp1228.pdf

Chen, D., \& Mintz, J. (2012, 09). Annual global tax competitiveness ranking - a Canadian good news story. SPP Resarch Papers, 5(28), 5, 9. Retrieved from 
http://www.policyschool.ucalgary.ca/?q=content/2012-annual-global-tax-competitivenessranking-canadian-good-news-story

Chua, D. (1995). The Concept of Cost of Capital: Marginal Effective Tax Rate on Investment. In P. Shome, Tax Policy Handbook (pp. 161-165). Washington D. C.: Fiscal Affairs Department, IMF.

Dunn, D., \& Pellechio, A. (1990). Analyzing taxes on business income with the marginal effective tax rate model. Washington, D.C.: The World Bank. Retrieved from http://wwwwds.worldbank.org/external/default/WDSContentServer/WDSP/IB/2000/01/15/000178830_98 101903573650/Rendered/PDF/multi_page.pdf

Gordon, R., Kalambokidis, L., \& Slemrod, J. (2003, 03). A new summary measure of the effective tax rate on investment. NBER Working Paper No. 9535. doi:10.3386/w9535

King, M. A., \& Fullerton, D. (1984). The Taxation of Income from Capital: A Comparative Study of the United States, the United Kingdom, Sweden, and Germany. Chicago and London: University of Chicago Press. Retrieved from http://papers.nber.org/books/king84-1

Krugman, P. R. (1983). Targeted industrial policies: theory and evidence. Retrieved from https://www.kansascityfed.org/publicat/sympos/1983/S83KRUGM.pdf

Lunina, I. (2011). Public finance and infrastructure development problems in the economy. Economy of Ukraine, 46-56. Retrieved from http://eng.economukraine.com.ua/

OECD. (2000). Towards Global Tax Cooperation: Progress in Identifying and Eliminating Harmful Tax Practices. OECD, Committee on Fiscal Affairs. Paris: OECD publications. Retrieved from http://www.oecd.org/tax/transparency/44430257.pdf

Shah, A. (Ed.). (1995). "Overview" in Fiscal Incentives for Investment and Innovation. Washington, D.C.: Oxford University Press for the World Bank.

Sokolovska, A. (2011, 05 20). Problemy monitorynhu efektyvnosti nadannja podatkovyx pil'h v Ukrajini. Finansy Ukrajiny(3), 42-53. Retrieved from http://www.minfin.gov.ua/control/uk/publish/article?art_id=293122\&cat_id=287157

Sokolovska, A., Efimenko, T., Lunina, I., R, B., \& Ziatkovskiy, V. (2006). A system of tax preferences in Ukraine in the context of European background. Kyiv: Scientific-research institute of Ministry of finance of Ukraine.

Zee, H. H., Stotsky, J., \& Ley, E. (2002). Tax Incentives for Business Investment: A Primer for Policy Makers in Developing Countries. World Development, 30(9), 1497-1516. doi:10.1016/S0305$750 \times(02) 00050-5$

Received for publication: $\quad 28.05 .2014$

Revision received: $\quad 11.08 .2014$

Accepted for publication: $\quad 24.08 .2014$

\section{How to cite this article?}

Style - APA Sixth Edition:

Nazukova, N. (2015, Jan 15). METR model for measuring tax burden on investment in Ukraine. (Z. Čekerevac, Ed.) MEST Journal, 3(1), 37-47. doi:10.12709/mest.03.03.01.05 
Style - Chicago Fifteenth Edition:

Nazukova, Nataliia. 2015. "METR model for measuring tax burden on investment in Ukraine." Edited by Zoran Čekerevac. MEST Journal (MESTE) 3 (1): 37-47. doi:10.12709/mest.03.03.01.05.

Style - GOST Name Sort:

Nazukova Nataliia METR model for measuring tax burden on investment in Ukraine [Journal] // MEST Journal / ed. Čekerevac Zoran. - Belgrade : MESTE, Jan 15, 2015. - 1 : Vol. 3. - pp. 37-47.

Style - Harvard Anglia:

Nazukova, N., 2015. METR model for measuring tax burden on investment in Ukraine. MEST Journal, 15 Jan, 3(1), pp. 37-47.

Style - ISO 690 Numerical Reference:

METR model for measuring tax burden on investment in Ukraine. Nazukova, Nataliia. [ed.] Zoran Čekerevac. 1, Belgrade : MESTE, Jan 15, 2015, MEST Journal, Vol. 3, pp. 37-47. 